\title{
Slavic Studies and Library Acquisitions
}

$\mathrm{T}$ He American pUblic recently has been made aware directly of the deep significance of developments in eastern Europe for their own individual interests and security. Hitherto, many Americans have been relatively complacent concerning their moral and physical superiority over the Soviet Union. Popular accounts and widely publicized statistics seemed to indicate clearly that the United States was far ahead of the Soviet Union and would maintain that supremacy for years to come. The confidence which was shared by most Americans was suddenly and dramatically destroyed by the sputniks which enabled each of us individually to see that although the Russians might lack chrome and fishtails on their cars, or might even lack private cars at all, they could still obtain tremendous successes in the scientific field, and in an area of great military significance. The advent of the sputniks has caused not only a reappraisal of our own educational system, but it has again brought to the fore the vital necessity for the continuation and rapid expansion of the study of the Slavic world by Americans and of the need for the continued acquisition of research materials which will enable us to judge accurately life and society in that area.

In view of the reawakened interest in Slavic studies and with the hope that the obvious challenge of Soviet power will

Dr. Jelavich is Associate Professor of History, University of California, Berkeley. This paper was presented before the meeting of the ALA Resources and Technical Services Division, Acquisitions Section, July 17, 1958, San Francisco. provoke the American public to extend their facilities for the acquisition of knowledge concerning their competitors, the following pages will be devoted to a discussion of some of the problems at present connected with Russian and East European studies and the library resources which are available on the subject. The basis for the following observations is some of the problems encountered, first, during the course of the survey at present being conducted by the Sub-Committee on the Review of Russian Studies under the auspices of the Joint Committee on Slavic Studies, and, second, on the simultaneous survey of the Slavic materials available in American libraries, which has been carried on by the Committee on Slavic and East European Studies of the Association of Research Libraries. These comments will probably be of interest primarily to the universities and libraries which at present do not have extensive library collections in the Slavic field but which are contemplating possible expansion.

It should be emphasized immediately that at present the level of American research on the basic subjects in the Slavic areas is very high indeed. The past years have produced a great expansion in the number of students interested in Slavic studies and an impressive number of publications in the field have recently appeared. American weakness is chiefly shown in the fact that study in the Slavic field has concentrated in a few disciplines and in relatively few centers. A well-known European scholar who came to the United States several years ago was tremendously impressed with the scholarly and scientific knowledge available concerning Russia and eastern Eu- 
rope, but he was astonished by the almost negligible impact which this has had on American public opinion. It is therefore the recognized task of those in the Slavic field to try to introduce Slavic studies on a more extensive basis throughout the country and to make the results of scholarly research available to a wider public.

Despite the present high level of accomplishment, Slavic studies in the United States are of relatively recent growth. Prior to 1914 only three or four American scholars were interested in Russia and only two or three libraries concerned themselves seriously with the collection of materials from that part of the world. Although from 1919 to 1939 an increasing number of scholars became interested in the Soviet Union, only a few of them were able to travel in eastern Europe or carry on serious research. Very little was accomplished as far as disseminating information on the area to the American electorate. The period between the wars did, nevertheless, bring to the United States a large number of political refugees, among whom were some excellent scholars who contributed to our knowledge of the Soviet Union. Within the State Department several individuals, among them, best known to the public, George Kennan and Charles Bohlen, became vitally concerned with Russian problems. However, despite certain advances, Slavic studies by 1939 had not progressed to a satisfactory degree. Thus in 1945, when the United States assumed its present position of international power and responsibility, both the government and the universities were in a difficult situation. The government agencies were so desperate for Slavic specialists that some of them were willing to accept those with even a meager knowledge of eastern Europe. The universities also realized that they would need to accelerate the training of specialists in this significant part of the world. Even those connected with radio and the newspapers suffered from the lack of competent observers and analysts. It was also painfully obvious that with the exception of the native Russians there were far too few in the United States who knew the Russian language.

Under the impetus of the new position in which the United States now found itself, a number of the universities acted quickly to provide facilities for further training in the Slavic area. Institutes and centers were established at California, Columbia, Harvard, and Washington. Despite their size and importance universities were immediately faced with serious problems concerning personnel and library acquisitions. In addition to the financing of the centers devoted to Russian and East European studies, appropriations had to be made to cover expansion within the existing departments. Fortunately, the universities received considerable encouragement and support from the foundations, in particular, from Ford, Rockefeller, and Carnegie. As a result of the initiative taken by the universities and the financial contributions of the foundations a remarkable degree of success was achieved during the succeeding decade.

In 1948 the American Council of Learned Societies and the Social Science Research Council organized the Joint Committee on Slavic Studies. The purpose of this group was to study the problems connected with Slavic studies and to provide guidance in future research. The committee eventually obtained funds which enabled it to publish the excellent collection of extracts from the Russian newspapers and journals entitled Current Digest of the Soviet Press, to hold scholarly conferences on subjects of particular interest in the Slavic field, to subsidize publications, and to offer grants-in-aid for research purposes.

In 1957 the Joint Committee decided 
that a survey should be made to determine what had been accomplished in the past and what should be done in the future. Some of the major questions examined were the following: Had the needs of the Slavic field been met? Was the research which had hitherto been conducted properly focused? What fields of investigation still had to be examined? Should there be more research centers for the training of future scholars? Should more Master's and doctoral candidates be trained and would these individuals obtain positions once they had completed their work? Would the administrators continue to provide funds for Slavic studies or would the contributions of the past and the present support eventually cease? Would the American libraries continue to be provided with the funds necessary to acquire indispensable research materials?

To conduct this survey a committee was organized under the chairmanship of Professor C. E. Black of Princeton, with Mr. John Thompson of the Social Science Research Council as staff. Other members of the committee included representatives from the universities of California, Columbia, Harvard, Indiana, and Washington and a representative from the library field. After carefully studying the problems involved, the committee agreed upon five major steps. First, it was decided that on each of the ten major disciplines a recognised scholar in the field should be asked to write a report of from twenty-five to thirty pages appraising the accomplishments of the past within his own field and indicating what areas of research still had to be investigated. This report was in turn sent to two outstanding scholars in the same discipline, one specifically not in the Slavic field, for their observations and comments. The ten disciplines covered were economics, geography, history, political science, literature, social relations, linguistics, philosophy and reli- gion, science, and the fine arts. Second, the committee decided to investigate the library holdings and the problems related to the acquisition of Slavic materials and the financing of the collections. Since it was clearly realized that the success of Slavic studies and, in particular, research in the Slavic area would depend directly on the materials available in American libraries, the committee obtained the cooperation of the Association of Research Libraries which agreed to oversee such a study. Thereafter, Melville Ruggles of the Council on Library Resources and Vaclav Mostecky, then of the Catholic University School of Library Science, conducted a survey of library resources in the Slavic field. In the course of their investigations they visited over forty libraries and sent detailed questionnaires to approximately five hundred others. Third, questionnaires were sent to all former students of the various Russian area centers and institutes to gather their views concerning their training and experiences and to request suggestions for the improvement of the training of Russian specialists in the future. Fourth, a questionnaire was distributed to the major universities concerned with the Slavic field asking for certain statistics and information on graduate education in Russian studies. Fifth, Professor Black and Mr. Thompson visited jointly or separately more than fifteen of the major American universities working in the Slavic field to ascertain what programs the universities were offering, what interests the faculty had, what plans were being formulated for the future, and what were the problems confronting the universities. The results of the survey, which was begun in the fall of 1957 , were discussed in three meetings held by the committee: in December in New York, in January at Harvard, and in March at the University of California, Berkeley. A majority of the scholars in 
the United States interested in Slavic studies were able to attend at least one of these meetings. Discussions were held concerning the preliminary findings and draft reports were examined. The results of these meetings and of the work of the committee as a whole will appear during 1959.

The preliminary unofficial statistical results of the survey indicate that in the postwar decade the major work in the Slavic area has been accomplished at five major centers: California, Columbia, Indiana, Harvard, and Washington. Seventy doctoral candidates have been produced and over seventy more are now working toward this degree. There have been also over five hundred Master's degrees. Of the doctoral candidates 25 per cent have been in history, 25 per cent in the languages and literature, and 19 per cent in economics. With respect to placement, 20 per cent are now teaching, 25 per cent are in government and academic research, and 27 per cent in operational government positions. The remainder have gone into the fields of radio, newspaper, business, law, and administration.

In addition to a study of the reports, the committee has discussed the question of the future direction of Slavic studies. The immediate postwar programs were inaugurated with the principal purpose of providing for the demands of the government and the academic community. Although these demands have not been completely filled, the need is not as acute as before. However, in many respects the problem has now become more complex. No longer can Russian and East European studies be regarded as esoteric subjects of interest only to the Department of State and university intellectuals. Instead, Russian and East European studies are clearly of interest and importance to all Americans. The challenge of Russia as a great power and in the scientific field has made it urgent that subject matter pertaining to the Slavic area be introduced into the undergraduate level at all colleges, not in just those specializing in the Slavic field, and even into the high school curriculum. The analogy of the scientist is here clearly appropriate. The scientist demands that the student learn mathematics at an early age; the social scientist, the humanist, and now, too, the scientist wish him to know Russian as soon as possible. In order to determine how material on the Slavic world could be introduced into the colleges and how the problem was to be dealt with on the local level, the committee undertook a pilot survey of undergraduate education in Indiana in cooperation with Indiana University. The purpose of this study was to bring together representatives of the thirty-four universities and colleges in Indiana to discuss the problems of area studies and the interest of these institutions in this field. It is hoped that the results of this study will provide a guide for the universities and colleges in other states. In addition, the committee, during the academic year 195859 , plans to investigate the question of Slav studies at the high school level, including the problem of language training.

Throughout this review of the Slavic field in the United States it was clearly apparent that the success of Slavic studies now and in the future would depend largely on the library resources available. The research scholar, the government worker, the teacher, are all dependent on the willingness and ability of individual libraries to develop and enlarge their collections. As Slavic studies are of necessity extended into lower educational levels it is important that all libraries, whether connected with educational institutions or with the cities, recognize the necessity of acquiring the standard works in the field. The survey on library resources, which will be pub- 
lished in the winter of $1958-59,1$ brought to light the unfortunate fact that Slavic materials are concentrated in the United States in a relatively few centers and that even these are not able to cover the field. Mr. Ruggles and Mr. Mostecky received 545 replies to their questionnaires from libraries having some Slavic materials; they conducted forty-six interviews with librarians and users of libraries throughout the United States. As a result of their study it appears that in the United States there are approximately $1,500,000$ monographs, 70,000 periodicals and 3,000 newspaper holdings. Of this material nearly 60 per cent is in the Russian field, which indicates that there must be an expansion in the acquisition of materials from non-Russian eastern European states. Of the materials available over 40 per cent are to be found in university libraries, over 25 per cent in government libraries, about 15 per cent in special libraries, such as the Hoover Library in Palo Alto, and over 15 per cent in public libraries, such as the New York Public Library. These figures sound impressive, but they really are not. It is obvious that American libraries cannot afford to purchase everything, nor is it desirable that they do so. However, the survey clearly indicates that our acquisitions could be improved in quality and coverage. In the choice of materials to be purchased it was revealed that very few universities have a systematic process of selection, whereas most purchases are made on a haphazard basis, usually upon the recommendations of individual faculty members who are chiefly interested in material in their field of research. Only a handful of American libraries use as a guide to book selection the comprehensive Soviet publication Knizhnaia Letopis, which lists the trade and society publications. Almost all of the East Eu-

\footnotetext{
1 A brief summary of the survey, written by Melville Ruggles, appears in the October 1958 issue of The Library Quarterly.
}

ropean countries have similar bibliographies, as for instance, the Jugoslav Bibliografija Jugoslavije. It should be noted here that these publications remain the best source for new material published in the Slavic countries.

As far as the acquisition of material is concerned the usual method of purchase and exchange has been found most satisfactory. Favorable conditions have meant good acquisitions, but a period of political tension has resulted in a severe decline of deliveries of new material. Both purchase and exchange are affected in this case.

Another problem confronting librarians is that of cataloging. In fact, it has been a deterring factor in some universities which would otherwise be interested in acquisitions in the field. Library of Congress cards have proved indispensable, but, at the same time, a cataloger must be available who can use the Slavic languages. Library schools, together with the area centers and institutes, should encourage more students to enter the field of Slavic bibliography. Any individual who has command of the Russian language can with a little additional preparation handle any of the other Slavic languages with the degree of fluency necessary for the cataloging of books.

After a thorough study of the library facilities has been completed, it seems that it will be possible to make some specific recommendations. For instance, the libraries should retain the principal responsibility for selection of materials, thereby providing the maximum degree of continuity in acquisitions. Although librarians should consult with faculty members, they should not rely exclusively on their recommendations. For those libraries which are interested in maintaining a strong Slavic collection, the two excellent monthly acquisition lists published by the Library of Congress, The Monthly Index of Russian 
Accessions and the East European Accessions Index, should be followed as well as the bibliographies of the various Slavic countries. In addition, each library should have at least one bibliographer with a knowledge of a Slavic language, preferably Russian. As far as acquisitions are concerned, each library must determine its own needs and the funds which it believes should be spent. All libraries, however, whether they are university, college, or city libraries, should have at least some books dealing with Russian history, and printed in Russian, as well as grammars and other aids for the teaching of the Russian language. Every opportunity should be made available to the young American to become acquainted with the Russian language and Russian history.

In addition to this, since it is clearly evident that all libraries cannot buy everything that is published, the major centers should undertake an extensive loan arrangement with other libraries. It is quite apparent that today many excellent scholars teaching in colleges and universities away from the large libraries are unable to continue their research in the Slavic field because of a lack of material. The libraries must be willing to loan extensively and on a cooperative basis to those who are unable to use their facilities directly.

In order to assure that the libraries in the United States as a whole cover all categories of Russian publications, particularly those in the less developed disciplines, it has been suggested that the universities adopt a system similar to the Farmington Plan. Under this the libraries would agree to purchase books by disciplines. It appears that with the exception of economics, history, government, and literature, the current holdings are far from satisfactory. The division of the less popular subjects among the libraries would assure that we would have within the United States the maxi- mum amount of research material on all phases of life in Russia.

The problems of the institutions which feel that they cannot make extensive purchases of Slavic publications and yet wish to give satisfactory courses in the area are very important. To meet this need it has been suggested that the specialists in the Slavic field, as well as those for the Far Eastern, Moslem, and African areas, which suffer from similar conditions, draw up a list of books whose total cost would be between $\$ 300$ and $\$ 500$ which every library should have as the indispensable minimum for the satisfactory education of our students as future citizens. If the individual student is encouraged to become interested in the Slavic world, he will be influenced to continue his studies on the graduate level. It is to be hoped that the colleges and smaller universities will thus become a recruiting ground for future scholars in the field. It is recognized that it is of the utmost importance that future Slavic studies and interest in the subject be as widespread as possible throughout the country and not centered so completely in the present major institutes.

Both the surveys of Slavic studies as a whole and the libraries in particular have clearly revealed the importance of the attitude of the university and college administrator toward the expansion and development of Slavic studies. It is most important that the individual librarian and faculty member convince the university administrator with whom he is most closely concerned that it is of vital necessity that the study of the Slavic world be expanded and developed. Certainly, the degree of accurate scholarship and intelligent knowledge reached by Americans in the future will be directly related to the research materials and general works available in American libraries. The demands of national security and the need of the individual who 
wishes to be better educated, and thereby become a more effective citizen, can be satisfied only if the libraries meet their obligations. It is to be hoped that in the future the expansion in Slavic studies and the acquisition of material on the Slavic world will not only continue in the large centers, but will be recognized as a major task by the universities and libraries throughout all of the states. In this matter the contribution of the librarian to American security and the furtherance of research and knowledge in this country can be more important and decisive than that of the military or the scientist.

\section{Micro-Publishing Projects}

A Sub-committee on Micro-publishing Projects was established at the 1958 San Francisco conference by the Resources Committee of ALA's Resources and Technical Services Division. The sub-committee will serve "as a coordinating body to which publishers who wish to inaugurate micro-publishing projects may turn for advice from librarians, and to which librarians may turn for advice when they are considering purchasing proposed micro-publishing projects."

The sub-committee has requested Richard B. Harwell, Associate Executive Director of ALA, to provide a focal point for its activities. Mr. Harwell will maintain a file of proposed micro-publishing projects and will be in a position to coordinate work by informing sponsors of projects whether or not similar projects are underway elsewhere. He should be addressed at the American Library Association, 50 East Huron Street, Chicago 11, Illinois. A note to him listing projects now active or proposed will be of considerable help in establishing an effective record of current activities and available micropublications.

In his report for the Committee on Resources of RTSD at San Francisco, Chairman RaIph Ellsworth noted: “The sub-committee will offer to explore with any sponsor or producer of microcopy the relative merits and potential market for any specific proposal, and advise as to whether a given project is really needed in its originally proposed scope and form, or whether some more selective scope or different format or other solution might be better. The sub-committee will also serve as a channel for inviting the consideration of producers in discovering ways and means of bringing into being other worthwhile microcopy projects suggested by librarians and scholars, or developed from studies of needs undertaken by the sub-committee itself."

The sub-committee consists of the following individuals: Edward B. Stanford, Librarian, University of Minnesota Libraries; Herman H. Fussler, Director of Libraries, University of Chicago; George Schwegmann, Chief, Union Catalog Division of the Library of Congress; Rudolf Hirsch, Assistant Director, University of Pennsylvania Library; Frederick $\mathrm{H}$. Wagman, Director, University of Michigan Library; Mr. Harwell; and Raynard C. Swank, Stanford University Libraries, who is chairman of this sub-committee. 